\title{
Research on High Efficiency Non-Isolated Push-Pull Converters with Continuous Current in Solar-Battery Systems
}

\author{
Yan $\mathrm{Li}^{*}$, Trillion Q. Zheng ${ }^{*}$, and Qian Chen ${ }^{\dagger}$ \\ ${ }^{*}$ School of Electrical and Engineering, Beijing Jiaotong University, Beijing, China
}

\begin{abstract}
In order to improve the output efficiency of solar cells and to extend the life span of batteries, the input currents of converters are required to be continuous. If low output voltage ripple is required at the same time, it is obvious that the application of basic two-order converters (such as Buck and Boost derived converters) will not be good enough. In this paper, a lot of non-isolated push-pull converters (NIPPCs) with continuous current will be introduced due to their lower current stress, higher efficiency and better EMC performance. By decomposing the converters into push-pull cells, inductor and free-wheeling diodes, two families of NIPPCs based on single inductor and coupled inductor separately are systematically generated. Furthermore, characteristics analyses for some of the generated converters are also shown in this paper. Finally, two prototypes based on the corresponding typical topologies are built in the lab to verify the theoretical outcomes.
\end{abstract}

Key words: Continuous Current, High Efficiency, Non-Isolated, Push-Pull Converter

\section{INTRODUCTION}

In order to improve the output efficiency of solar cells and to extend the life span of batteries, converters with continuous input current are required in solar-battery power systems [1], [2]. Therefore, Buck derived converters are not suitable for these power systems, as can be seen from the input current waveform shown in Fig.1(a). Boost derived converters can be chosen in these systems, but the output current is discontinuous. If the requirements for the output voltage ripple are very strict, these topologies are not suitable. To solve these problems, an LC (or a large C) filter should be added to basic second-order converters [3]-[5] (such as Buck and Boost derived converters). This will make the current in the LC filter side (Refer to Fig.1(b)) continuous. However, this will add the system cost, weight and volume. In addition it will accentuate electrolytic capacitor reliability and electrical resonance issues. These shortcomings can be circumvented if the converter draws continuous and

Manuscript received Oct. 29, 2013; accepted Jan. 17, 2014

Recommended for publication by Associate Editor Joung-Hu Park.

${ }^{\dagger}$ Corresponding Author: chenqian05291148@126.com

Tel: +86-10-51684911-20, Fax: +86-10-51684029, Beijing Jiaotong University

* School of Electrical and Eng., Beijing Jiaotong University, China controllable current at the input and output stages [6], [7]. The peak and the RMS values of the current through each device in the continuous current converters are reduced. As a result, low current stress of the devices and good EMC performance can be achieved.

In order to achieve continuous current, adding another inductor and capacitor into these basic second-order converters is a possible method. [8]-[10] introduce a family of fourth-order converters with continuous current. Superbuck and Superboost converters are typical of many of these. The waveforms of the input and output current are triangular, as shown in Fig.1(c). From the small-signal mathematical model, it can be seen that they are fourth-order because they contain four storage elements. These converters are hard to design due to the high order feature and the right half phase zero (RHPZ).

Another improvement method is to introduce a transformer and several free-wheeling diodes into a non-isolated DC/DC converter. This can provide a current path to the output capacitor when all of the switches are off. Due to their simple circuit configuration, the isolated push-pull converters are widely used in dc power supplies. As a result, non-isolated push-pull converters with continuous current (NIPPCs) are proposed. Add on smart [11]-[15] and Weinberg [15]-[18] converters are typical of many of these. When compared with 


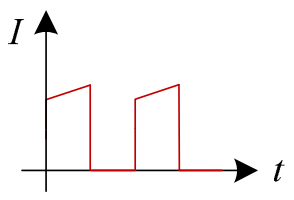

(a)



(c)

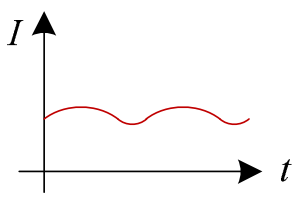

(b)

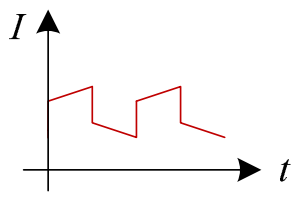

(d)
Fig. 1. Input current of (a) Buck derived converters (b) Buck derived converters with LC filter (c) high-order converters (b) non-isolated push-pull converters.

the converters mentioned in [8]-[10], the NIPPCs have complex circuit configurations, but they have many other advantages. From the small-signal mathematical model, it is a typical second-order system without the RHPZ. The continuous current allows for an excellent output voltage quality[11]-[18]. The bias magnetic problem will not be seriously deteriorated due to the inductor which is connected between the power supply and the transformer.

The objective of this paper is to propose a systematic method to synthesize NIPPCs. Two families of NIPPCs are considered. The first one is generated by a single inductor and the second one is generated by a coupled inductor. When compared to the topologies in [11]-[18], multiple voltage gain styles will appear in the generated topologies, which is suitable for the wide range battery voltage. Some of the novel generated converters have high efficiency, high power density and excellent output voltage quality. In addition, the input current of the Weinberg converter [15]-[18] is shown in Fig. 1(d), which is pulsating with two-level value. Similarly, the input or output current of the other generated NIPPC topologies are pulsating with two-level value as well. The difference between the high and low-level values of the current become smaller, which results in a compact size for the filter.

\section{WEINBERG CONVERTER}

The Weinberg converter [15]-[18] is a typical example of the NIPPC. The circuit configuration and key waveforms are sketched in Fig.2. Suppose that the self-inductances in the primary and secondary are $L_{N P 1}$ and $L_{N S 1}$, respectively. To achieve a low-ripple output current, $N_{P 1}=N_{S 1}, \quad N_{P}=N_{S}$, $L_{N P 1}=L_{N S 1}=L_{1}$ and the mutual inductance coefficient is 1 . When $Q_{1}$ or $Q_{2}$ is on, equations (1) and (2) are satisfied; when $Q_{1}$ and $Q_{2}$ are off, equations (3) and (4) are satisfied. $D$ is

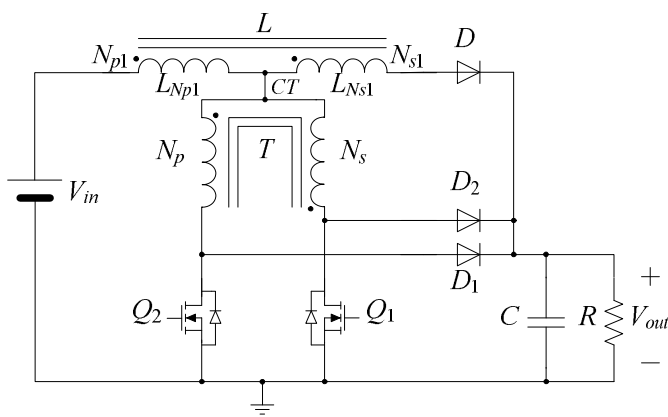

(a)

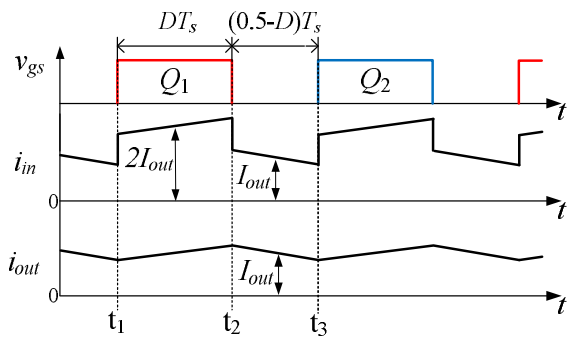

(b)

Fig. 2. Weinberg converter's (a) main circuit (b) waveforms of $v_{g s}, i_{\text {in }}$ and $i_{\text {out }}$.

defined as the switch duty ratio. While considering the voltage-second balance of the inductor, the voltage gain can be derived as equation (5). From Fig.2(a), it can be seen that the NIPPC is composed of an inductor, a push-pull cell and additional free-wheeling diodes.

$$
\begin{gathered}
i_{\text {in }}(t)=2 I_{\text {out }} \quad\left(t_{1} \sim t_{2}\right) \\
\Delta i_{\text {out }}(+)=\frac{V_{\text {in }}-V_{\text {out }} / 2}{2 L_{1}} D \cdot T_{s} \quad\left(t_{1} \sim t_{2}\right) \\
i_{\text {in }}(t)=I_{\text {out }} \quad\left(t_{2} \sim t_{3}\right) \\
\Delta i_{\text {out }}(-)=\frac{V_{\text {in }}-V_{\text {out }}}{4 L_{1}} \cdot(0.5-D) \cdot T_{s} \quad\left(t_{2} \sim t_{3}\right) \\
V_{\text {out }}=(1+2 D) V_{\text {in }}
\end{gathered}
$$

\section{BASIC AND DERIVED NON-ISOLATED PUSH-PULl CELLS}

The function of push-pull cell is to provide a pulsating current or voltage. Thus, push-pull cell consists of switch network and transformer. The secondary ground $\mathrm{H}$ of the classical isolated push-pull cell is connected with terminal $\mathrm{F}$ (shown in Fig. 3(a)), and it is referred to as push-pull cell I. The classical isolated push-pull cell is referred to as push-pull cell II, as shown in Fig. 3(b). The secondary ground $\mathrm{H}$ of the classical isolated push-pull cell is connected with terminal $\mathrm{E}$ of the two paralleled forward cells, and the four-winding transformer can be separated into two sets of independent transformer $\left(N_{p}\right.$ and $N_{s}$ ' constitute transformer 1 , and $N_{p}$ ' and $N_{s}$ constitute transformer 2). However, it can be seen that the 


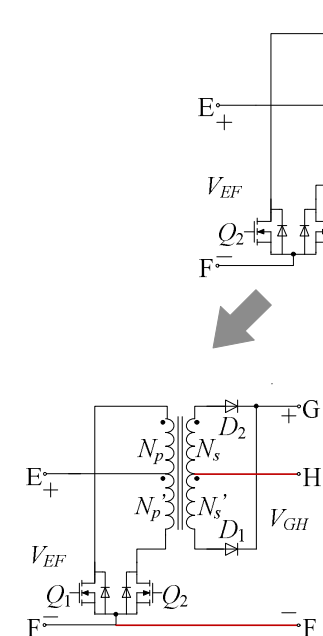

(b) push-pull cell II



(a) push-pull cell I



(d) push-pull cell IV

(e) push-pull cell V



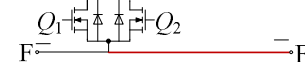

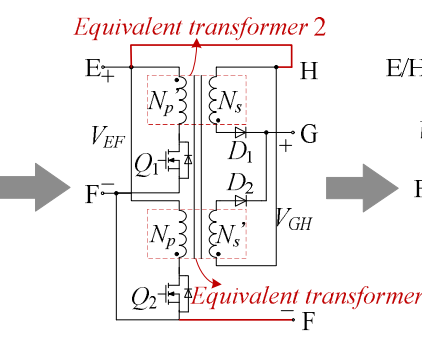

$Q_{2}+\stackrel{-16 \text { Equivalent tr }}{\mathrm{F}}$

Fig. 3. Derivation process of five non-isolated push-pull cells.

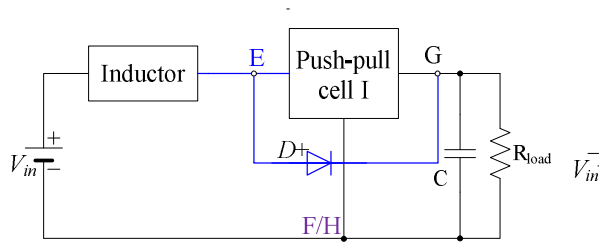

(a)

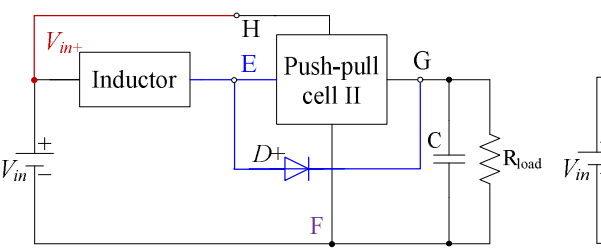

(b)

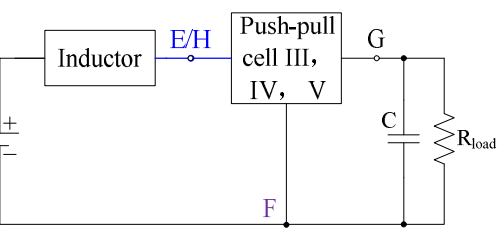

(c)

Fig. 4. Block diagram of the NIPPCs with continuous current based on single inductor generated by (a) push-pull I (b) push-pull II (c) push-pull III, IV and V.

current only flows through one set of transformers when $Q_{1}$ or $Q_{2}$ is on, which allows for low power density. Therefore, $N_{s}$ and $N_{s}^{\prime}$ are removed and the anodes of $D_{1}$ and $D_{2}$ are connected with the drain poles of $Q_{2}$ and $Q_{1}$, respectively, and push-pull cell III, shown in Fig. 3(c), is generated. The converters with continuous current generated by push-pull cell III save two windings. As a result, the power density can be improved. Due to the exchange of the primary and secondary windings with the modal changes, these topologies are non-isolated. In order to obtain a higher voltage gain, two windings are inserted between the transformer and the switches, and push-pull cell IV, shown in Fig. 3(d), is generated. When two windings are added between the transformer and diode, push-pull cell $\mathrm{V}$ is generated as shown in Fig. 3(e).

\section{SYNTHESIS OF NON-ISOLATED PUSH-PULL CONVERTERS WITH CONTINUOUS CURRENT}

By analyzing the circuit configuration of the Weinberg converter shown in Fig. 2, it can be concluded that this converter is derived from the classical current-fed push-pull converter. The input current of the classical current-fed push-pull converter is continuous, while its output current is discontinuous. In order to achieve continuous output current, a diode which provides a free-wheeling path for the inductor current should be added into the Weinberg converter. Similarly, the existence of the input inductor will keep the input current continuous and the push-pull cell cooperating with the free-wheeling diodes will make the output current continuous. Therefore, the inductor, non-isolated push-pull cell and free-wheeling diode are the possible elements when building NIPPCs. In a current-fed push-pull converter, the inductor is close to the input source and the push-pull cell should be connected with a capacitor type filter in order to ensure power transfers without incompatible switching conditions. From the basic circuit theory, closing a voltage-source-capacitor loop or opening a current-sourceinductor leads to incompatible boundary conditions at the switching instant which causes infinite current or voltage impulses. The connection style of the inductor, push-pull cell and capacitor is shown in Fig. 4.

In push-pull cell $\mathrm{I}$, an additional diode needs to be added between terminals $E$ and $G$ in order to obtain continuous output current, and the corresponding NIPPC structure is shown in Fig. 4(a). If terminal $\mathrm{H}$ in push-pull cell II is connected with $V_{i n^{+}}$and an additional diode is added between terminals E and G, a NIPPC can be generated as Fig. 4(b). For push-pull cells III, IV and V, the connection style of the inductor, push-pull cell and capacitor is shown in Fig. 4(c), and additional diodes are not required in these NIPPCs since 


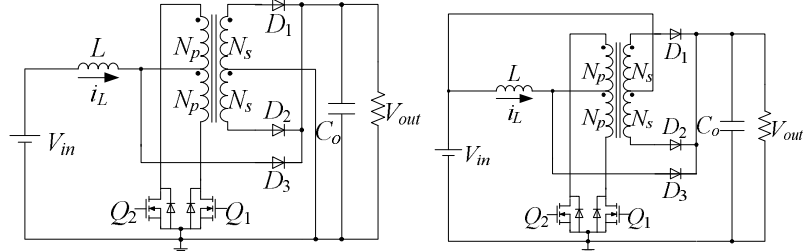

(a)

(b)

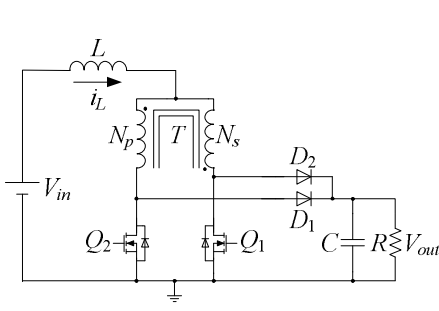

(c)

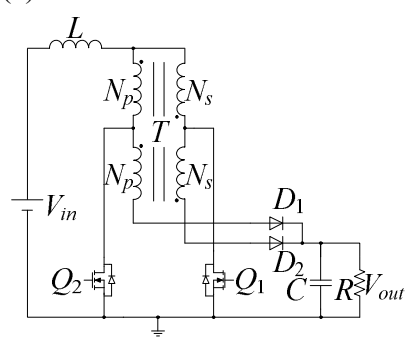

(e)

Fig. 5. NIPPCs synthesized by single inductor and (a) push-pull cell I (Is) (b) push-pull cell II (IIs) (c) push-pull cell III (IIIs) (d) push-pull cell IV (IVs) (d) push-pull cell V (Vs).

the diodes of push-pull cells III, IV and V are reused as free-wheeling diodes.

Provided that $N_{p}=N_{p}, N_{s}=N_{s}$, the turn ratio of the coupled inductor is $N_{1}=N_{p 1} / N_{s 1}$, the turn ratio of the transformer is $N_{2}=N_{p} / N_{s}$ and the current flowing through the inductor when $Q_{1}$ or $Q_{2}$ is on is defined as $i_{1} . D$ is the duty ratio of the MOSFET.

\section{A. Synthesis of Non-Isolated Push-Pull Converters with a Single Inductor}

According to the above synthesis rule, five NIPPCs are generated by a single inductor and five push-pull cells. Fig. 5 shows the NIPPCs based on a single inductor and five types of push-pull cells, which are referred as Is [15], IIs [14], IIIs, IVs and Vs converters, respectively. The free-wheeling diode $D_{3}$ should be added to produce the freewheeling by-passes for a single inductor $L$. However, for topologies IIIs, IVs and Vs, there is no need to add any free-wheeling diodes because the inductor releases energy through the rectifier diodes $D_{1}$ and $D_{2}$, which enhances the utilization of the diodes and power density.

It should be noted that continuous current means that the current does not go to zero at any time. In the input and output currents of the NIPPCs with continuous current, one of these NIPPCs is low-ripple which is similar to the

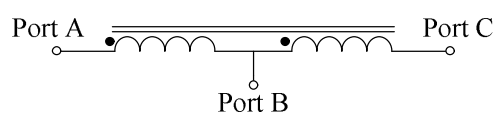

(a)

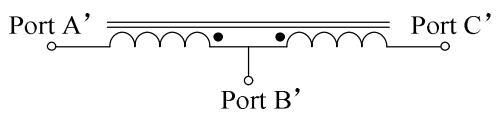

(b)

Fig. 6. Circuit configuration of (a) positive direction coupling inductor (b) negative-direction coupling inductor.

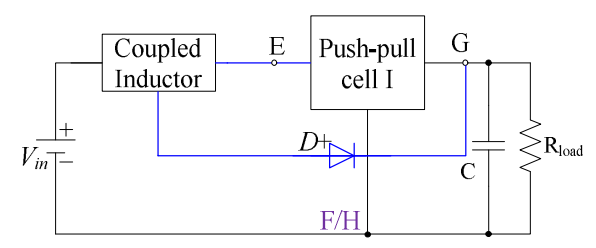

(a)

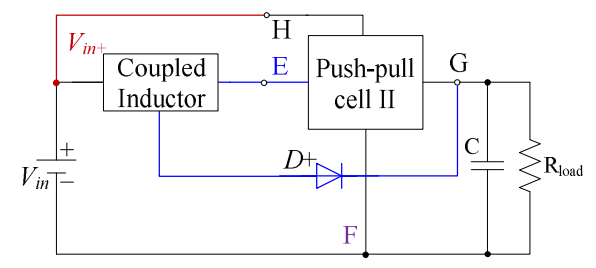

(b)

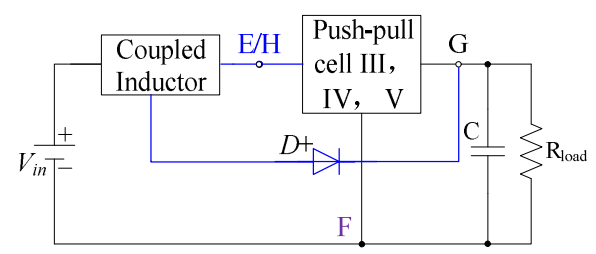

(c)

Fig. 7. Block diagram of the NIPPCs with continuous current based on coupled inductor generated by (a) push-pull I (b) push-pull II (c) push-pull III, IV and V.

inductor current and the other one is pulsating and its waveform contains two-level value and each level is not zero.

The performances of the NIPPCs with a single inductor are shown in Tables II and III. Among them, topology IIs can realize low-ripple output current while the other topologies can realize low-ripple input current.

\section{B. Synthesis of Non-Isolated Push-Pull Converters with a Coupled Inductor}

Unlike single inductor, there are three terminals in a coupled inductor and there are two coupling modes of integrated magnetic. The terminals of the positive direction coupling mode are named A, B and C while the terminals of the negative-direction coupling mode are named A', B' and C', as shown in Fig. 6. Similar to Fig. 4, Fig. 7 shows the 
TABLE I

Twelve Ways of Configuring Three-Terminal Coupled Inductor to External Circuit

\begin{tabular}{|c|c|c|c|c|c|c|c|c|c|c|c|c|}
\hline Configuration & $\mathrm{c}-1$ & $\mathrm{c}-2$ & c-3 & c-4 & c-5 & c-6 & $\mathrm{c}-7$ & c-8 & c-9 & $\mathrm{c}-10$ & $\mathrm{c}-11$ & $\mathrm{c}-12$ \\
\hline Vin+ & $\mathrm{A}$ & A & $\mathrm{B}$ & $A^{\prime}$ & $\mathrm{A}^{\prime}$ & $\mathrm{B}^{\prime}$ & $\mathrm{B}$ & $\mathrm{C}$ & $\mathrm{C}$ & $\mathrm{B}^{\prime}$ & $\mathrm{C}^{\prime}$ & $\mathrm{C}^{\prime}$ \\
\hline Terminal E in push-pull cell & $\mathrm{B}$ & $\mathrm{C}$ & A & $\mathrm{B}^{\prime}$ & $\mathrm{C}^{\prime}$ & $A^{\prime}$ & $\mathrm{C}$ & A & $\mathrm{B}$ & $C^{\prime}$ & $A^{\prime}$ & $\mathrm{B}^{\prime}$ \\
\hline $\mathrm{D}+$ & $\mathrm{C}$ & B & $\mathrm{C}$ & $\mathrm{C}^{\prime}$ & $\mathrm{B}^{\prime}$ & $\mathrm{C}^{\prime}$ & A & B & A & $A^{\prime}$ & $\mathrm{B}^{\prime}$ & $A^{\prime}$ \\
\hline
\end{tabular}

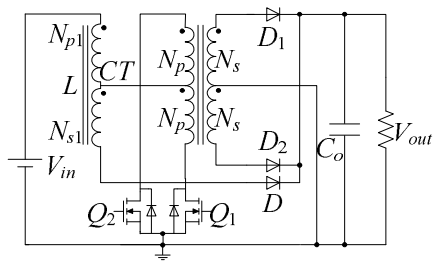

(a)

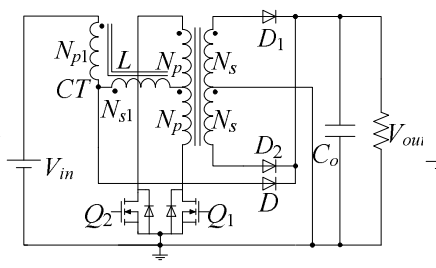

(b)

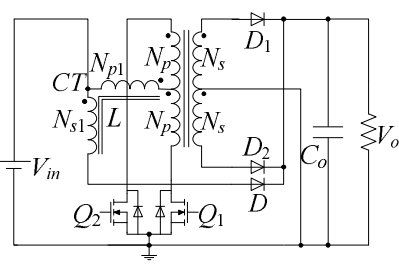

(c)

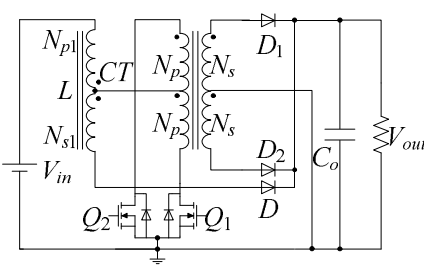

(d)

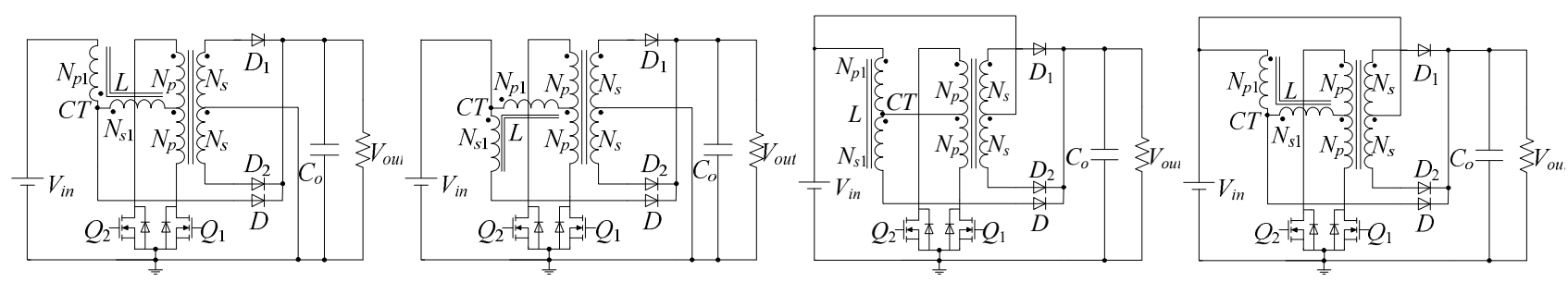

(e)

(f)

(g)

(h)

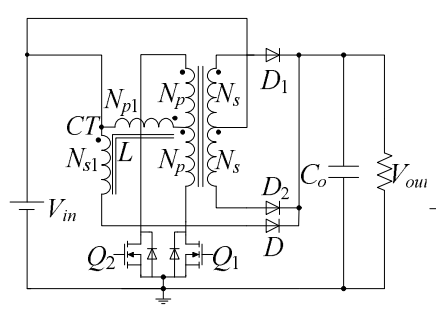

(i)

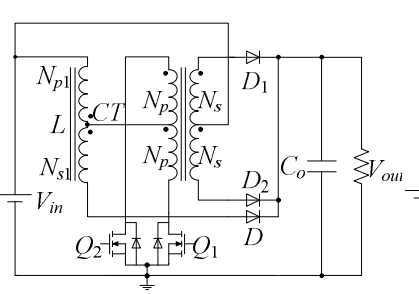

(j)

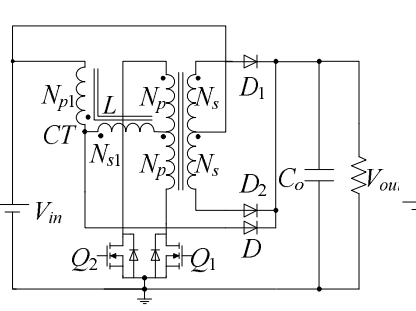

(k)

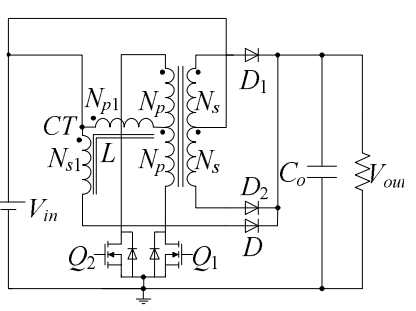

(1)

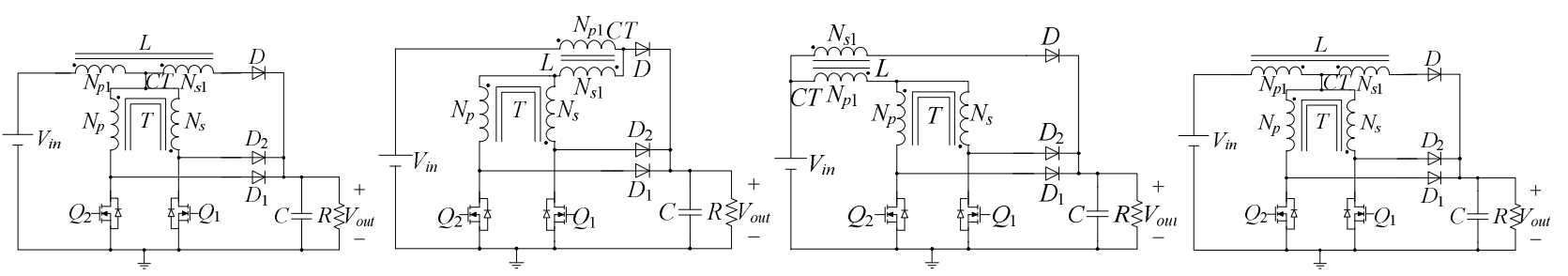

(m)

(n)

(o)

(p)

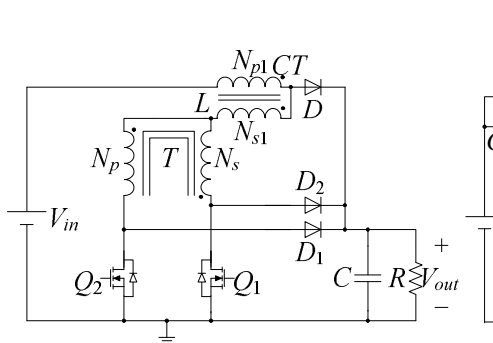

(q)

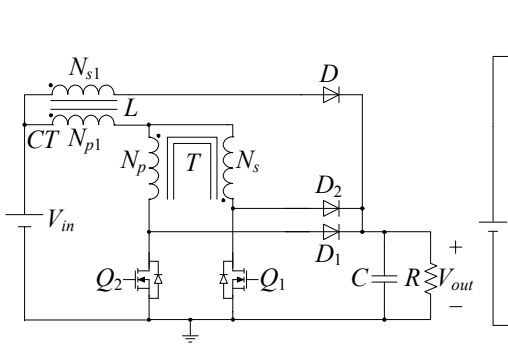

(r)

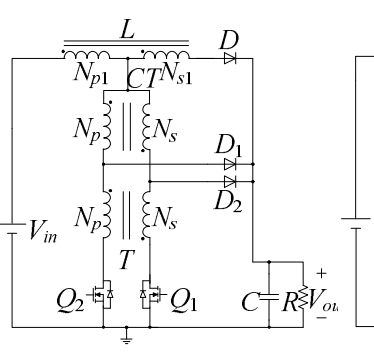

(s)

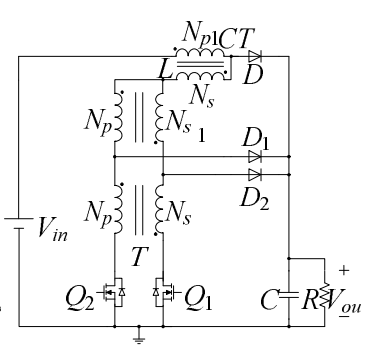

(t) 


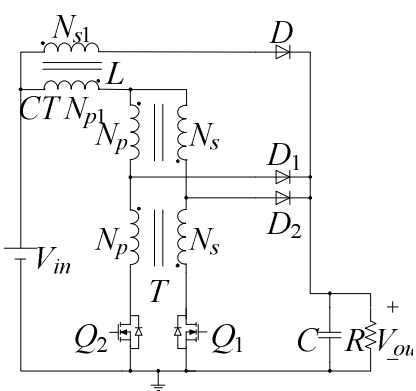

(u)

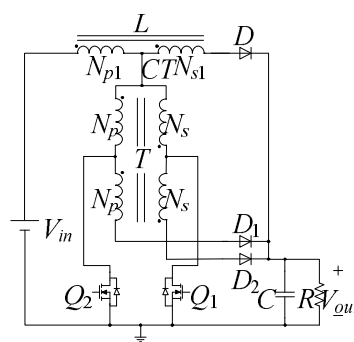

(y)

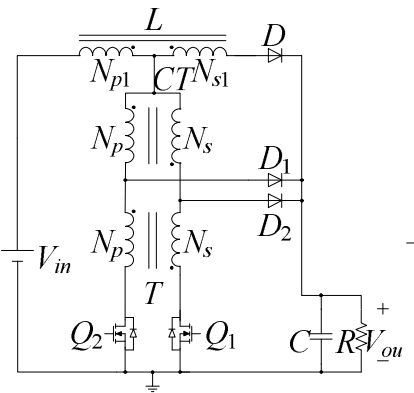

(v)

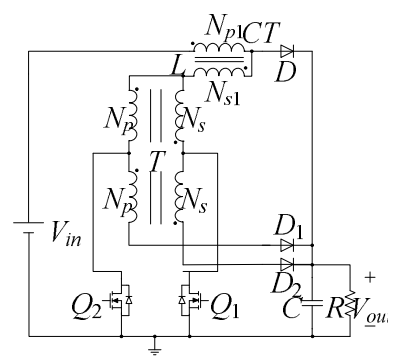

$(\mathrm{z})$

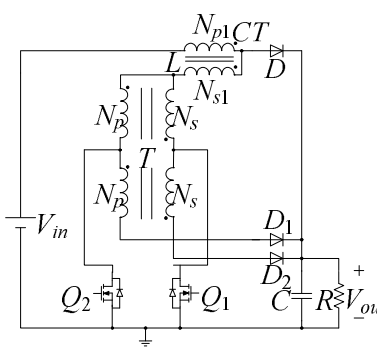

(ac)

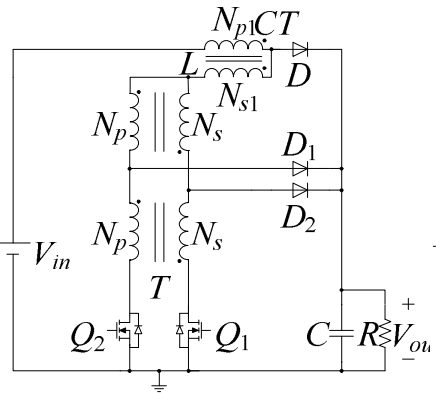

(w)

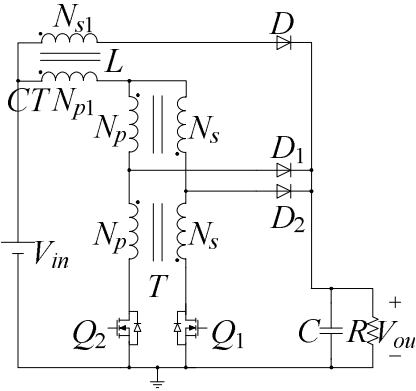

$(\mathrm{x})$

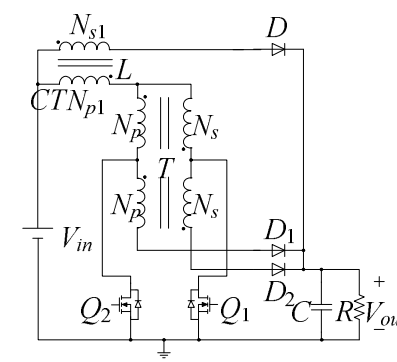

(aa)

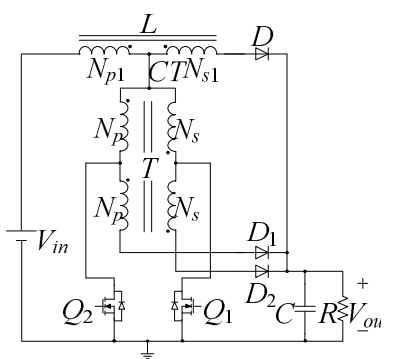

$(\mathrm{ab})$



(ad)

Fig. 8. Coupled inductor NIPPCs synthesized by (a) push-pull cell I and configuration c-1 (Ic-1) (b) push-pull cell I and configuration c-2 (Ic-2) (c) push-pull cell I and configuration c-3 (Ic-3) (d) push-pull cell I and configuration c-4 (Ic-4) (e) push-pull cell I and configuration c-5 (Ic-5) (f) push-pull cell I and configuration c-6 (Ic-6) (g) IIc-1 (h) IIc-2 (i) IIc-3 (j) IIc-4 (k) IIc-5 (1) IIc-6 (m) IIIc-1 (n) IIIc-2 (o) IIIc-3 (p) IIIc-4 (q) IIIc-5 (r) IIIc-6 (s) IVc-1 (t) IVc-2 (u) IVc-3 (v) IVc-4 (w) IVc-5 (x) IVc-6 (y) Vc-1 (z) Vc-2 (aa) Vc-3 (ab) Vc-4 (ac) Vc-5 (ad) Vc-6.

block diagram of the NIPPCs generated by coupled inductor. One terminal of the coupled inductor should be chosen to connect to the free-wheeling diode. When compared with the NIPPCs with a single inductor, the turn ratio of the coupled inductor can be designed properly to generate more topologies with excellent characteristics.

The three terminals of coupled inductor can be connected with the external circuit in twelve ways, which are shown in Table I. Therefore, the NIPPCs generated by the coupled inductor are more than those of the single inductor. Since configurations c-1 6 are equivalent to c-12 7, respectively, thirty NIPPCs can be generated based on coupled inductor. In total, thirty-five NIPPCs can be generated according to the synthesizing rules.

Due to the diversity of the ways of configuring the coupled inductor, the number of the coupled inductor topologies is more than that of the single inductor topologies. Therefore, they are classified according to the push-pull cells and the configurations of coupled inductor. For example, topology Ic- 2 is generated by push-pull cell I and configurations c- 2 .

The performances of the NIPPCs with coupled inductor are shown in Tables II and III. Since the input and output currents of topologies Ic-2 and Ic-4 are not continuous, these topologies are not discussed here. For topology Ic-3, when $Q_{1}$ and $Q_{2}$ are both off, the anode voltage of the freewheeling diode $D$ is lower than the cathode voltage and the inductor cannot release its stored energy and will be saturated. As a result, this converter cannot operate normally. The NIPPCs synthesized by the other four push-pull cells and the coupled inductors based on configuration c-3 (IIc-3, IIIc-3, IVc-3 and Vc-3) cannot operate normally for the same reasons. Hereafter, these five topologies are referred as quasi-NIPPCs. 


\section{CONVERTER CHARACTERISTICS}

When compared with the traditional push-pull converter, the NIPPCs take advantage of efficiency. The high efficiency is mainly reflected in the following three aspects:

1) For the traditional push-pull converter, all of the power is regulated through the MOSFET. However, for the NIPPCs, most of the power is transferred to the load directly rather than passing through the MOSFET. As a result, the switching loss is reduced dramatically and high efficiency can be easily achieved.

2) For some of the proposed topologies in this paper, the leakage inductance of the transformer reduces $\mathrm{di} / \mathrm{dt}$ and the turn-on loss can be neglected. The switching loss will be reduced without additional elements or a complicated control strategy.

3) The output current of the traditional push-pull converter is discontinuous while the output currents of some of the proposed topologies in this paper are low-ripple. Therefore, the RMS of the capacitor current of the traditional push-pull converter is higher than the proposed topologies in this paper. The power loss which is introduced by the ESR of traditional push-pull converter is much higher.

When compared with the traditional push-pull converter, the other advantages of the NIPPCs are shown as follows:

1) The output current of the traditional push-pull converter is discontinuous while the input and output currents of NIPPCs are continuous. Continuous input and output currents result in many benefits:

- Reductions of the spike and RMS of current. As a result, MOSFETs with low current stress can be chosen and the power loss will be reduced.

- Reductions in the volume of the filter to enhance the power density and dynamic performance.

- Enhancement of the EMC.

- They are good for sensing the current accurately.

2) The right half phase zero exists in the control to output transfer function of the traditional push-pull converter. As a result, the control system is hard to design. For some of the proposed topologies in this paper, the right half phase zero does not exist in the control to output transfer function and the control system is easy to design.

Taken together, the NIPPCs are prior to the traditional push-pull converter.

For clarity, the NIPPCs and the quasi-NIPPCs are listed in this paper. First, all of the topologies are proposed except for topologies Is[15], IIs[14], IIIc-1[13-17] and IIIc-6[18]. Among the thirty five topologies, topologies IIIc-2, IIIc-4 and IIIc-6 (with low-ripple input current) are equivalent to topology IIIs; topologies IVc-2, IVc-4 and IVc-6 (with low-ripple input current) are equivalent to topology IVs; and topologies Vc-2, Vc-4 and Vc-6 (with low-ripple input current) are equivalent to topology Vs. The quasi topologies and the equivalent topologies are ignored and twenty one NIPPCs can be obtained including seventeen novel topologies.

It should be noted that this paper only focuses on the NIPPCs with continuous input and output currents and that it discusses the characteristics of these topologies. When compared with the single inductor NIPPCs, the coupled inductor NIPPCs have the advantages of smaller inductor volume, higher efficiency and wider application. Due to the complexity of the coupled inductor NIPPCs, these topologies are focused on especially. Some of the conclusions are shown as follows:

1) All of the NIPPCs are based on configuration c-3 of coupled inductor and cannot operate normally since the inductor cannot release its stored energy.

2) In order to obtain the same ripple current, the value of the inductor based on the negative-direction coupling mode is higher than that of the forward-direction coupling mode. Therefore, the NIPPCs based on the forward-direction coupling mode have higher power density.

3) The NIPPCs based on configurations c-4 and c-5 can only operate normally when $N_{1}>1$. Due to the negative-direction coupling mode, $N_{1}$ is designed to be more than 2 to avoid too large current ripple. The current cannot flow through the primary and secondary windings simultaneously for the NIPPC based on configuration c- 6 . As a result, the power density of this topology is higher than that of the NIPPCs based on configurations c-4 and c-5. For the same reason, the power loss of the coupled inductor in these two types of topologies is the lowest among all of the NIPPCs based on coupled inductor.

4) For the NIPPCs based on push-pull cells III, IV and $\mathrm{V}$, in order to realize $\Delta i_{\text {out }}(+)=\Delta i_{\text {out }}(-)$ in one equivalent period, $N_{2}=1$. However, there is no such constraint for the NIPPCs based on push-pull cells I and II, so $N_{1}$ and $N_{2}$ are uncertain.

5) Among the NIPPCs based on push-pull cells III, IV and $\mathrm{V}$, if the output voltage and the maximum duty ratio are confirmed, the input voltage range of the NIPPCs based on push-pull cell V is the widest while that of the NIPPCs based on push-pull cell IV is the narrowest.

6) For the coupled inductor NIPPCs based on push-pull cells III, IV and V, the NIPPCs based on configuration c-2 satisfied $V_{c l}>V_{D+}$. Therefore, the inductor releases its stored energy through the primary and secondary windings of the transformer and these topologies are equivalent to a single 
inductor topology. For the NIPPCs with a coupled inductor based on configurations c-4 and c-5, $N_{1}>1$ should be satisfied to make them operate normally. The NIPPCs based on configuration c-4 are equivalent to a single inductor topology. When the input current ripple of the NIPPCs based on configuration c-6 is low, they are equivalent to a single inductor topology. It should be mentioned that the single inductor topology can only realize low-ripple input current.

Multiple voltage gain styles appear in the novel coupled inductor NIPPCs, for example (1+D), $(1+4 \mathrm{D})$ and so on, where $(1+4 \mathrm{D})$ is suitable for the application of a battery with wide range voltage.

Table II shows the performance of the NIPPCs with low-ripple output current. High performance of the bus voltage is needed. The voltage stress of the switches, the voltage gain, the description of the input current and the low-ripple condition of $I_{\text {out }}$ are shown too. The minimum value of $V_{b a t}$ is calculated when $V_{\text {in }}=V_{\text {bat }}, V_{\text {out }}=42 \mathrm{~V}$, and $D_{\max }=0.5$, and the range of the battery voltage is obtained. Table III shows the performance of the NIPPCs with low-ripple input current. This table also shows the voltage stress of the switches, the voltage gain, the description of the output current and the low-ripple condition of $I_{i n}$. The maximum value of $V_{b a t}$ is calculated when $V_{i n}=V_{b u s}=42 \mathrm{~V}$, $V_{\text {out }}=V_{b a t}$, and $D_{\max }=0.5$, and the range of the battery voltage is obtained.

\section{EXPERIMENTAL RESULTS}

In this paper, two topologies are chosen to verify the theoretical analysis, which are shown as follows.

\section{A Verification Based on a Prototype of Topology IIIs}

Due to its simple structure, the power density of topology IIIs is prior to the other topologies. Therefore, a $500 \mathrm{~W}$ prototype with the novel generated topology IIIs was built in the lab to verify the above theoretical analysis. The specifications are shown as follows, $V_{b a t}=45 \sim 60 \mathrm{~V}$, $i_{\text {bat }}=1 \mathrm{~A} \sim 8 \mathrm{~A}, V_{\text {bus }}=42 \mathrm{~V}, L=45 \mathrm{uH}, C_{o}=600 \mathrm{uF}, f_{s}=100 \mathrm{kHz}$, $N_{2}=1$, MOSFET: FB260N and Diode: 30CPQ150.

Topology IIIs is shown in Fig. 9(a). Fig. 9(b) gives the experimental waveforms of $i_{\text {in }}$ and $i_{\text {out }}$ when $V_{b a t}=45 \mathrm{~V}$ and $I_{b a t}=1 \mathrm{~A}$. Fig. 9(c) gives the experimental waveforms of $i_{i n}$ and $i_{\text {out }}$ when $V_{b a t}=60 \mathrm{~V}$ and $I_{b a t}=8 \mathrm{~A}$, where the input current ripple is low and the output current is pulsating where the high-level is $i_{1}$ and the low-level is $0.5 i_{1}$. The efficiency is higher than $95 \%$ in all of the cases and the maximum is $98.1 \%$, as shown in Fig. 9(d).

\section{$B$ Verification Based on a Prototype of Topology $V_{c-1}$}

In the application of $V_{b a t}=20 \mathrm{~V} \sim 32 \mathrm{~V}$ and $V_{b u s}=42 \mathrm{~V}$, the high voltage gain topology will be adaptable. Topology $\mathrm{Vc}-1$ with a voltage gain $(1+4 D)$ can meet this demand among these

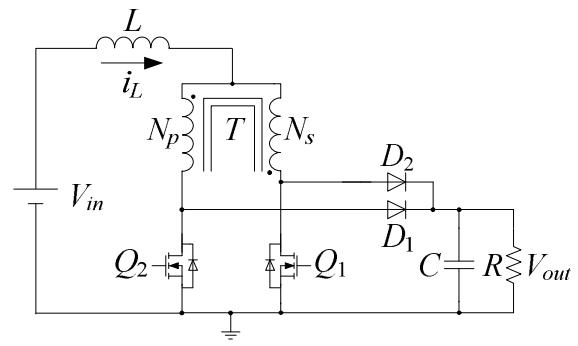

(a)

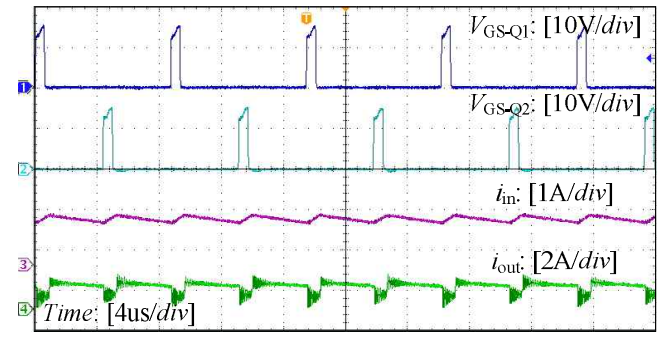

(b)

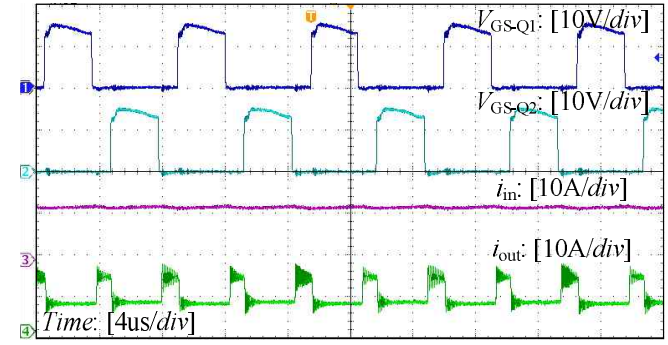

(c)



(d)

Fig. 9. Experimental results of (b) when $V_{b a t}=45 \mathrm{~V}, i_{b a t}=1 \mathrm{~A}$ (c) $V_{b a t}=60 \mathrm{~V}, i_{b a t}=8 \mathrm{~A}$ (d) efficiency curves of (a) topology IIIs.

generated topologies. Therefore, a 500W prototype was built in the lab. The specifications are shown as follows, $i_{\text {bat }}=1 \mathrm{~A} \sim 8 \mathrm{~A}, \quad C_{o}=600 \mathrm{uF}, f_{s}=100 \mathrm{kHz}, \quad N_{1}=0.5, \quad N_{2}=1: 1: 1: 1$, primary self inductor $L_{N P 1}=15 \mathrm{uH}$, secondary self inductor $L_{N S 1}=60 \mathrm{uH}$, mutual inductor $L_{M}=29.6 \mathrm{uH}$, MOSFET: FB260N and Diode: 30CPQ150. Topology $\mathrm{V}_{\mathrm{c}-1}$ is shown in Fig. 10(a). Fig. 10(b) gives the experimental waveforms of $i_{\text {in }}$ and $i_{\text {out }}$ when $V_{b a t}=20 \mathrm{~V}$ and $I_{b a t}=8 \mathrm{~A}$. Fig. 10 (c) gives the experimental waveforms of $i_{\text {in }}$ and $i_{\text {out }}$ when $V_{b a t}=32 \mathrm{~V}$ and $I_{b a t}=1 \mathrm{~A}$. It can be seen from Fig. 10 that the output current ripple is low, while the input current is pulsating. The high-level of the input current is $i_{1}$ and the low-level is $1 / 3 i_{1}$. The efficiency curves are shown in Fig. 10(d). The minimum efficiency is $94.8 \%$ 
TABLE II

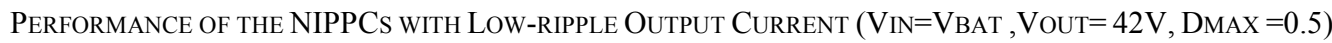

(a)

\begin{tabular}{|c|c|c|c|c|c|c|c|c|c|}
\hline & IIs & Ic-1 & Ic-5 & Ic-6 & IIc-1 & IIc-2 & IIc-4 & IIc-5 & IIc-6 \\
\hline $\begin{array}{l}\text { Voltage } \\
\text { stress of } \\
Q_{1} 、 Q_{2}\end{array}$ & $2 V_{\text {out }}{ }^{-} V_{\text {in }}$ & $\begin{array}{c}2 N_{1} V_{\text {out }} / \\
\left(N_{1}+1\right)+ \\
V_{\text {in }} /\left(N_{1}+1\right)\end{array}$ & $\begin{array}{c}2\left(N_{1}-1\right) V_{\text {out }} / \\
N_{1}+V_{\text {in }} / N_{1}\end{array}$ & $\begin{array}{l}2 N_{1} V_{\text {out }}+ \\
\left(1-N_{1}\right) V_{\text {in }}\end{array}$ & $\begin{array}{l}2 N_{1} V_{\text {out }} / \\
\left(N_{1}+1\right)+ \\
\left(1-N_{1}\right) V_{\text {in }} \\
/\left(N_{1}+1\right)\end{array}$ & $\begin{array}{l}\left(2+2 / N_{1}\right) \\
V_{\text {out }}-(1+ \\
\left.2 / N_{1}\right) V_{\text {in }}\end{array}$ & $\begin{array}{c}2 N_{1} V_{\text {out }} \\
\left(N_{1}-1\right) \\
-\left(1+N_{1}\right) V_{\text {in }} / \\
\left(N_{1}-1\right)\end{array}$ & $\begin{array}{c}(2-2 / \\
\left.N_{1}\right) V_{\text {out }} \\
+\left(2 / N_{1-}\right. \\
1) V_{\text {in }}\end{array}$ & $\begin{array}{c}2 N_{1} V_{\text {out }} \\
+(1- \\
\left.2 N_{1}\right) V_{\text {in }}\end{array}$ \\
\hline$V_{\text {out }} / V_{\text {in }}$ & $1+2 D$ & $\begin{array}{c}\left(N_{1}+2 D\right) / \\
N_{1}\end{array}$ & $\begin{array}{c}\left(N_{1}-1+2 D\right) / \\
\left(N_{1}-1\right)\end{array}$ & $\begin{array}{c}\left(N_{1}-2 D N_{1}+2 D\right) / \\
N_{1}\end{array}$ & $\begin{array}{c}\left(2 N_{1} D+\right. \\
\left.N_{1}+2 D\right) / N_{1}\end{array}$ & $\begin{array}{l}\left(2 N_{1} D+\right. \\
\left.N_{1}+1\right) / \\
\left(N_{1}+1\right)\end{array}$ & $\begin{array}{c}\left(2 N_{1} D-\right. \\
\left.2 D+N_{1}\right) / N_{1}\end{array}$ & $\begin{array}{c}\left(2 N_{1} D+\right. \\
\left.N_{1}-1\right) / \\
\left(N_{1}-1\right)\end{array}$ & $\begin{array}{l}(2 D+ \\
\left.N_{1}\right) / N_{1}\end{array}$ \\
\hline $\begin{array}{l}\text { High and } \\
\text { low-level } \\
\text { of } I_{i n}\end{array}$ & $\begin{array}{l}\mathrm{H}: 2 i_{1} \\
\mathrm{~L}: i_{1}\end{array}$ & $\begin{array}{c}\mathrm{H}: i_{1} \\
\mathrm{~L}: N_{1} i_{1} / \\
\left(N_{1}+1\right)\end{array}$ & $\begin{array}{c}\mathrm{H}: i_{1} \\
\mathrm{~L}:\left(N_{1}-1\right) i_{1} / \\
N_{1}\end{array}$ & $\begin{array}{c}\mathrm{H}: i_{1} \\
\mathrm{~L}: N_{1} i_{1}\end{array}$ & $\begin{array}{c}\mathrm{H}:\left(2 N_{1}+\right. \\
1) i_{1} /\left(N_{1}+1\right) \\
\mathrm{L}: N_{1} i_{1} / \\
\left(N_{1}+1\right)\end{array}$ & $\begin{array}{c}\mathrm{H}:\left(2 N_{1}+\right. \\
1) i_{1} / N_{1} \\
\mathrm{~L}:\left(N_{1}+\right. \\
1) i_{1} / N_{1}\end{array}$ & $\begin{array}{c}\mathrm{H}:\left(2 N_{1}\right. \\
-1) i_{1} / \\
\left(N_{1}-1\right) \\
\mathrm{L}: N_{1} i_{1} / \\
\left(N_{1}-1\right)\end{array}$ & $\begin{array}{c}\mathrm{H}:\left(2 N_{1^{-}}\right. \\
1) i_{1} / N_{1} \\
\mathrm{~L}:\left(N_{1^{-}}\right. \\
1) i_{1} / N_{1}\end{array}$ & $\begin{array}{c}\mathrm{H}:\left(N_{1}+\right. \\
1) i_{1} \\
\mathrm{~L}: N_{1} i_{1}\end{array}$ \\
\hline $\begin{array}{l}\text { Low-ripple } \\
\text { condition } \\
\text { of } I_{\text {out }}\end{array}$ & $N_{2}=1$ & $\begin{array}{c}N_{2}= \\
N_{1} /\left(N_{1}+1\right) \\
N_{1} \text { is } \\
\text { arbitrary }\end{array}$ & $\begin{array}{c}N_{2}= \\
\left(N_{1}-1\right) / N_{1} \\
N_{1}>1\end{array}$ & $\begin{array}{c}N_{2}=N_{1} \\
N_{1}<1\end{array}$ & $\begin{array}{c}N_{2}=N_{1} / \\
\left(N_{1}+1\right) \\
N_{1} \text { is } \\
\text { arbitrary }\end{array}$ & $\begin{array}{c}N_{2}=\left(N_{1}+\right. \\
1) / N_{1} \\
N_{1} \text { is } \\
\text { arbitrary }\end{array}$ & $\begin{array}{c}N_{2}= \\
N_{1} /\left(N_{1}-1\right) \\
N_{1}>1\end{array}$ & $\begin{array}{c}N_{2}=\left(N_{1-}\right. \\
1) / N_{1} \\
N_{1}>1\end{array}$ & $\begin{array}{c}N_{2}=N_{1} \\
N_{1} \text { is } \\
\text { arbitrary }\end{array}$ \\
\hline $\begin{array}{l}\text { Minimum } \\
\text { of } V_{b a t}\end{array}$ & $21 \mathrm{~V}$ & $\begin{array}{c}42 N_{1} / \\
\left(N_{1}+1\right) \mathrm{V}\end{array}$ & $\begin{array}{c}42\left(N_{1}-1\right) / \\
N_{1} \mathrm{~V}\end{array}$ & $42 N_{1} \mathrm{~V}$ & $\begin{array}{c}42 N_{1} / \\
\left(2 N_{1}+1\right) \mathrm{V}\end{array}$ & $\begin{array}{l}42\left(N_{1}+1\right) / \\
\left(2 N_{1}+1\right) \mathrm{V}\end{array}$ & $\begin{array}{c}42 N_{1} / \\
\left(2 N_{1}-1\right) \mathrm{V}\end{array}$ & $\begin{array}{l}42\left(N_{1}-1\right) / \\
\left(2 N_{1}-1\right) \mathrm{V}\end{array}$ & $\begin{array}{c}42 N_{1} / \\
\left(N_{1}+1\right) \mathrm{V}\end{array}$ \\
\hline
\end{tabular}

(b)

\begin{tabular}{|c|c|c|c|c|c|c|c|c|c|}
\hline & IIIc-1 & IIIc-5 & IIIc-6 & IVc-1 & IVc-5 & IVc-6 & Vc-1 & Vc-5 & Vc-6 \\
\hline $\begin{array}{l}\text { Voltage } \\
\text { stress of } \\
Q_{1} 、 Q_{2}\end{array}$ & $V_{\text {out }}$ & $V_{\text {out }}$ & $V_{\text {out }}$ & $4 V_{\text {out }} / 3$ & $4 V_{\text {out }} / 3$ & $4 V_{\text {out }} / 3$ & $\left(2 V_{\text {out }}+V_{\text {in }}\right) / 3$ & $\left(2 V_{\text {out }}+V_{\text {in }}\right) / 3$ & $\left(2 V_{\text {out }}+V_{\text {in }}\right) / 3$ \\
\hline$V_{\text {out }} / V_{\text {in }}$ & $1+2 D$ & $1+2 D$ & $1+2 D$ & $1+D$ & $1+D$ & $1+D$ & $1+4 D$ & $1+4 D$ & $1+4 D$ \\
\hline $\begin{array}{c}\text { High and } \\
\text { low-level } \\
\text { of } I_{\text {in }}\end{array}$ & $\begin{array}{c}\mathrm{H}: i_{1} \\
\mathrm{~L}: 0.5 i_{1}\end{array}$ & $\begin{array}{c}\mathrm{H}: i_{1} \\
\mathrm{~L}: 0.5 i_{1}\end{array}$ & $\begin{array}{c}\mathrm{H}: i_{1} \\
\mathrm{~L}: 0.5 i_{1}\end{array}$ & $\begin{array}{c}\text { H: } i_{1} \\
\text { L: } 2 i_{1} / 3\end{array}$ & $\begin{array}{c}\text { H: } i_{1} \\
\text { L: } 2 i_{1} / 3\end{array}$ & $\begin{array}{c}\text { H: } i_{1} \\
\text { L: } 2 i_{1} / 3\end{array}$ & $\begin{array}{c}\mathrm{H}: i_{1} \\
\mathrm{~L}: i_{1} / 3\end{array}$ & $\begin{array}{c}\text { H: } i_{1} \\
\text { L: } i_{1} / 3\end{array}$ & $\begin{array}{c}\text { H: } i_{1} \\
\text { L: } i_{1} / 3\end{array}$ \\
\hline $\begin{array}{c}\text { Low-ripple } \\
\text { condition } \\
\text { of } I_{\text {out }}\end{array}$ & $N_{2}=N_{1}=1$ & $N_{1}=2 N_{2}=2$ & $N_{2}=2 N_{1}=1$ & $N_{1}=2 N_{2}=2$ & $N_{1}=3 N_{2}=3$ & $N_{2}=1.5 N_{1}=1$ & $N_{2}=2 N_{1}=1$ & $N_{2}=2 N_{1} / 3=1$ & $N_{2}=3 N_{1}=1$ \\
\hline $\begin{array}{c}\text { Minimum } \\
\text { of } V_{b a t}\end{array}$ & $21 \mathrm{~V}$ & $21 \mathrm{~V}$ & $21 \mathrm{~V}$ & $28 \mathrm{~V}$ & $28 \mathrm{~V}$ & $28 \mathrm{~V}$ & $14 \mathrm{~V}$ & $14 \mathrm{~V}$ & $14 \mathrm{~V}$ \\
\hline
\end{tabular}


TABLE III



(a)

\begin{tabular}{|c|c|c|c|c|c|c|c|}
\hline & Is & IIIs & IVs & Vs & IIc-2 & IIc-4 & IIc-6 \\
\hline $\begin{array}{l}\text { Voltage } \\
\text { stress of } \\
Q_{1} 、 Q_{2}\end{array}$ & $V_{\text {out }}+N_{2} V_{\text {out }}$ & $V_{\text {out }}$ & $4 V_{\text {out }} / 3$ & $2 V_{\text {out }} / 3$ & $\begin{array}{l}\left(2 / N_{1}+1\right) V_{\text {out }} \\
-\left(2 / N_{1}\right) V_{\text {in }}\end{array}$ & $\begin{array}{c}\left(N_{1}+1\right) V_{\text {out }} / \\
\left(N_{1}-1\right) \\
-2 V_{\text {in }} /\left(N_{1}-1\right)\end{array}$ & $\begin{array}{l}\left(2 N_{1}-1\right) V_{\text {out }} \\
2\left(N_{1}-1\right) V_{\text {in }}\end{array}$ \\
\hline$V_{\text {out }} / V_{\text {in }}$ & $1 /\left(1-2 D+2 N_{2} D\right)$ & $1 /(1-D)$ & $1 /(1-2 D / 3)$ & $1 /(1-4 D / 3)$ & $\begin{array}{c}\left(N_{1}+1\right) / \\
\left(N_{1}+1-2 N_{1} D\right)\end{array}$ & $\begin{array}{c}N_{1} /\left(N_{1^{-}}\right. \\
\left.2 D N_{1}+2 D\right)\end{array}$ & $N_{1} /\left(N_{1}-2 D\right)$ \\
\hline $\begin{array}{c}\text { High and } \\
\text { low-level } \\
\text { of } I_{\text {out }}\end{array}$ & $\begin{array}{c}\mathrm{H}: i_{1} \\
\mathrm{~L}: N_{2} i_{1}\end{array}$ & $\begin{array}{c}\mathrm{H}: i_{1} \\
\mathrm{~L}: 0.5 i_{1}\end{array}$ & $\begin{array}{c}\mathrm{H}: i_{1} \\
\mathrm{~L}: 2 i_{1} / 3\end{array}$ & $\begin{array}{c}\mathrm{H}: i_{1} \\
\mathrm{~L}: i_{1} / 3\end{array}$ & $\begin{array}{c}\mathrm{H}: \\
\left(N_{1}+1\right) i_{1} / N_{1} \\
\text { L: } i_{1} / N_{1}\end{array}$ & $\begin{array}{c}\mathrm{H}: \\
N_{1} i_{1} /\left(N_{1}-1\right) \\
\text { L: } i_{1} /\left(N_{1}-1\right)\end{array}$ & $\begin{array}{c}\mathrm{H}: N_{1} i_{1} \\
\mathrm{~L}:\left(N_{1}-1\right) i_{1}\end{array}$ \\
\hline $\begin{array}{l}\text { Low-ripple } \\
\text { Condition } \\
\text { of } I_{\text {in }}\end{array}$ & $N_{2}<1$ & $N_{2}=1$ & $N_{2}=1$ & $N_{2}=1$ & $\begin{array}{c}N_{2}=1 / N_{1} \\
\quad N_{1} \text { is } \\
\text { arbitrary }\end{array}$ & $\begin{array}{c}N_{2}=1 /\left(N_{1}-1\right) \\
N_{1}>1\end{array}$ & $\begin{array}{c}N_{1}=N_{2}+1 \\
\qquad N_{1} \text { is } \\
\text { arbitrary }\end{array}$ \\
\hline $\begin{array}{c}\text { Maximun } \\
\text { of } V_{b a t}\end{array}$ & $42 / N_{2}$ & $84 \mathrm{~V}$ & $63 \mathrm{~V}$ & $126 \mathrm{~V}$ & $42\left(N_{1}+1\right) \mathrm{V}$ & $42 N_{1} \mathrm{~V}$ & $42 N_{1} /\left(N_{1}-1\right) \mathrm{V}$ \\
\hline
\end{tabular}

(b)

\begin{tabular}{|c|c|c|c|c|c|c|c|c|c|}
\hline & IIIIc-2 & IIIc-4 & IIIc-6 & IVc-2 & IVc-4 & IVc-6 & $\mathrm{Vc}-2$ & Vc-4 & Vc-6 \\
\hline $\begin{array}{l}\text { Voltage } \\
\text { stress of } \\
Q_{1} 、 Q_{2}\end{array}$ & $V_{\text {out }}$ & $V_{\text {out }}$ & $V_{\text {out }}$ & $4 V_{\text {out }} / 3$ & $4 V_{\text {out }} / 3$ & $4 V_{\text {out }} / 3$ & $2 V_{\text {out }} / 3$ & $2 V_{\text {out }} / 3$ & $V_{\text {out }}$ \\
\hline$V_{\text {out }} / V_{\text {in }}$ & $1 /(1-D)$ & $1 /(1-D)$ & $1 /(1-D)$ & $1 /(1-2 D / 3)$ & $1 /(1-2 D / 3)$ & $1 /(1-2 D / 3)$ & $1 /(1-4 D / 3)$ & $1 /(1-4 D / 3)$ & $1 /(1-4 D / 3)$ \\
\hline $\begin{array}{l}\text { High and } \\
\text { low-level } \\
\text { of } I_{\text {out }}\end{array}$ & $\begin{array}{c}\mathrm{H}: i_{1} \\
\mathrm{~L}: 0.5 i_{1}\end{array}$ & $\begin{array}{c}\mathrm{H}: i_{1} \\
\mathrm{~L}: 0.5 i_{1}\end{array}$ & $\begin{array}{c}\mathrm{H}: i_{1} \\
\mathrm{~L}: 0.5 i_{1}\end{array}$ & $\begin{array}{c}\text { H: } i_{1} \\
\text { L: } 2 i_{1} / 3\end{array}$ & $\begin{array}{c}\text { H: } i_{1} \\
\text { L: } 2 i_{1} / 3\end{array}$ & $\begin{array}{c}\text { H: } i_{1} \\
\text { L: } 2 i_{1} / 3\end{array}$ & $\begin{array}{c}\mathrm{H}: i_{1} \\
\mathrm{~L}: i_{1} / 3\end{array}$ & $\begin{array}{c}\text { H: } i_{1} \\
\text { L: } i_{1} / 3\end{array}$ & $\begin{array}{c}\mathrm{H}: i_{1} \\
\mathrm{~L}: i_{1} / 3\end{array}$ \\
\hline $\begin{array}{l}\text { Low-ripple } \\
\text { Condition } \\
\text { of } I_{i n}\end{array}$ & $\begin{array}{c}N_{2}=1 \\
N_{1} \text { is } \\
\text { arbitrary }\end{array}$ & $\begin{array}{l}N_{2}=1 \\
N_{1}>1\end{array}$ & $N_{1}=N_{2}=1$ & $\begin{array}{c}\quad N_{2}=1 \\
N_{1} \text { is } \\
\text { arbitrary }\end{array}$ & $\begin{array}{l}N_{2}=1 \\
N_{1}>1\end{array}$ & $N_{1}=N_{2}=1$ & $\begin{array}{c}N_{2}=1 \\
N_{1} \text { is } \\
\text { arbitrary }\end{array}$ & $\begin{array}{l}N_{2}=1 \\
N_{1}>1\end{array}$ & $N_{1}=N_{2}=1$ \\
\hline $\begin{array}{c}\text { Maximun } \\
\text { of } V_{b a t}\end{array}$ & $84 \mathrm{~V}$ & $84 \mathrm{~V}$ & $84 \mathrm{~V}$ & $63 \mathrm{~V}$ & $63 \mathrm{~V}$ & $63 \mathrm{~V}$ & $126 \mathrm{~V}$ & $126 \mathrm{~V}$ & $126 \mathrm{~V}$ \\
\hline
\end{tabular}




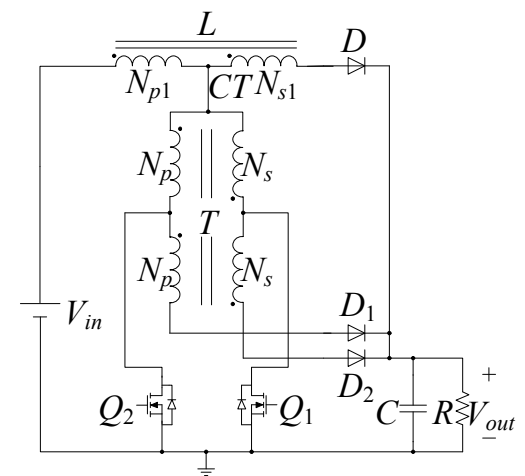

(a)

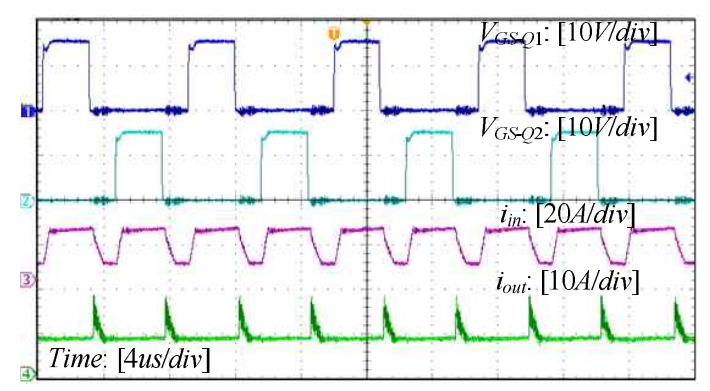

(b)

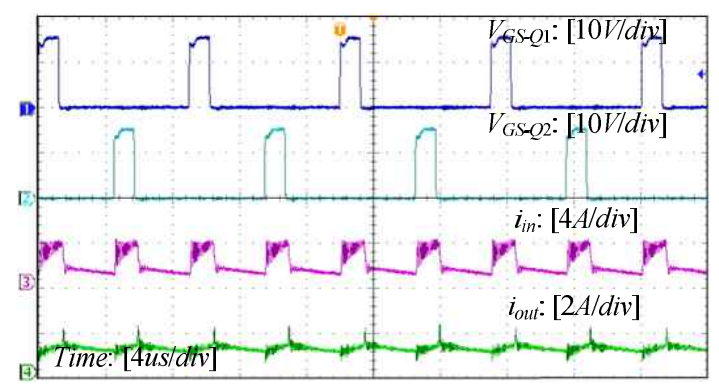

(c)

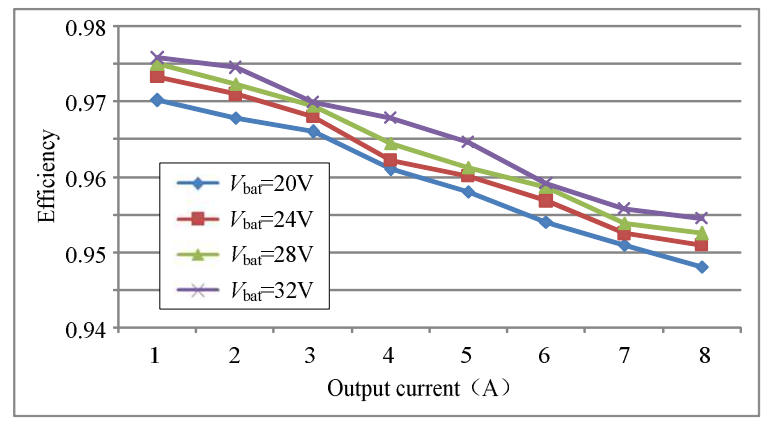

(d)

Fig. 10. Experimental results of (b) when $V_{b}=20 \mathrm{~V}, \mathrm{i}_{\text {out }}=8 \mathrm{~A}$ (c) when $V_{b a t}=32 \mathrm{~V}, i_{\text {out }}=1 \mathrm{~A}$ (d) efficiency curves of (a) topology Vc-1.

when $V_{\text {bat }}=20 \mathrm{~V}$ and $I_{\text {out }}=8 \mathrm{~A}$, and the maximum efficiency is $97.6 \%$ when $V_{b a t}=32 \mathrm{~V}$ and $I_{\text {out }}=1 \mathrm{~A}$. The efficiency decreases with the increase in the load current and decrease in the battery voltage.

\section{CONCLUSIONS}

In this paper, a systematic synthesizing method for non-isolated push-pull converters (NIPPCs) with continuous current is proposed. One single inductor with five types of push-pull cells can be combined into five NIPPCs with a single inductor. Six ways of configuring the three-terminal coupled inductor to the external circuit and five types of push-pull cells can be combined to form thirty NIPPCs with a coupled inductor. Multiple voltage gain styles appear in the novel NIPPCs, such as $(1+\mathrm{D} / 2),(1+2 \mathrm{D})$, $(1+4 \mathrm{D})$ and so on, which is suitable for the application of wide range battery voltage. Lower ripple current, higher efficiency, better EMC performance of the NIPPCs with continuous current have been achieved in this paper.

Finally, two prototypes referred as IIIs and Vc-1 were built in the lab to verify the converter operation.

\section{REFERENCES}

[1] L. Quan and P. Wolfs, "A review of the single phase photovoltaic module integrated converter topologies with three different DC link configurations," IEEE Trans. Power Electron., Vol. 23, No. 3, pp. 1320-1333, May 2008.

[2] Y. Xue, L. Chang, and S. B. Kjær, "Topologies of single-phase inverters for small distributed power generators: An overview," IEEE Trans. Power Electro., Vol. 19, No. 5, pp. 1305-1314, Sep. 2004.

[3] B. Zhao, Q. Yu, and W. Sun, "Extended-phase-shift control of isolated bidirectional DC-DC converter for power distribution in microgrid," IEEE Trans. Power Electron., Vol. 27, No. 11, pp. 4667-4680, Nov. 2012.

[4] O. Hegazy, J. V. Mierlo, and P. Lataire, "Analysis, modeling, and implementation of a multidevice interleaved DC/DC converter for fuel cell hybrid electric vehicles," IEEE Trans. Power Electron., Vol. 27, No. 11, pp. 4445-4458, Nov. 2012.

[5] C. N. Onwuchekwa and A. Kwasinski, "A Modified-TimeSharing Switching Technique for Multiple-Input DC-DC Converters," IEEE Trans. Power Electron., Vol. 27, No. 11, pp. 4492-4502, Nov. 2012.

[6] B. W. Williams, "DC-to-DC converters with continuous input and output power," IEEE Trans. Power Electron., Vol. 28, No. 5, pp. 2307-2316, May 2013.

[7] Q. Chen, T. Q. Zheng, Y. Li, and T. Shao, "The effect of transformer leakage inductance on the steady state performance of push-pull based converter with continuous current," Journal of Power Electronics, Vol. 13, No. 3, pp. 349-361, May 2013.

[8] A. Garrigos, J. A. Carrasco, J. M. Blanes, and E. Sanchis-Kilders, "A power conditioning unit for high power GEO satellites based on the sequential switching shunt series regulator," in Proc. MELECON, pp. 1186-1189, 2006.

[9] L. Soubrier, P. Besdel, T. Daubresse, and E. Trehet, "High performance BDR for the PCU of alpha bus," in Proceeding of 8th European Space Power Conference, SP-661, 2008. Available: http://www.esa.int/esapub/pi/proceedingsPI.htm

[10] T. Roinila, M. Hankaniemi, T. Suntio, M. Sippola, and M. Vilkko, "Dynamical profile of a switched-mode converter reality or imagination," in Proc. 29th INTELEC Conference, pp. 420-427, 2007.

[11] T. Sammaljarvi, F. Lakhdari, M. Karppanen, and T. Suntio, 
"Modeling and dynamic characterization of peak current mode controlled superboost converter," IET Power Electronics, Vol. 1, No. 4, pp. 527-536, Dec. 2008.

[12] J. Aroca, D. Olsson, and J. Maicas, "An efficient BDR topology, able to handle a large battery voltage range," in Proc. 5th European Space Power Conference, SP-416, 1998. Available: http://www.esa.int/esapub/pi/proceedingsPI.htm

[13] A. H. Weinberg and P. Rueda Boldo, "A high power, high frequency, DC to DC converter for space applications," in Proc. IEEE PESC Conference, pp. 1140-1147, 1992.

[14] W. Denzinger and W. Dietrich, "Generic 100V/high power bus conditioning," in Proc. 7th European Space Power Conference, SP-589, 2005. Available: http://www.esa.i nt/esapub/pi/procee dingsPI.htm

[15] D. O'Sullivian and M. Martin, "Rational behind the smart regulator," in Proc. 4th European Space Power Conference. pp. 47-54, SP-369, 1995. Available: http://www.esa.in t/esapub/pi/proceedingsPI.htm

[16] E. Maset, J. B. Ejea, and A. Ferreres, "High-efficiency weinberg converter for battery discharging in aerospace applications," in Proc. IEEE APEC Conference, pp. 1510-1516, 2006.

[17] E. Maset and A. Ferrers, " $5 \mathrm{~kW}$ Weinberg converter for battery discharging in high-power communications satellites," in Proc. IEEE PESC Conference, pp. 69-75, 2005.

[18] A. H. Weinberg, "The battery discharge of the galileo satellite test bed-V2A power system using the weinberg topology," in Proc. 7th European Space Power Conference, SP-589, 2005. Available: http://www.esa.int/esapub/pi/pro ceedingsPI.htm

[19] D. O'Sullivan, "Space power electronics-design drivers," ESA Journal, Vol. 18, No. 1, pp. 1-23, 1994.

[20]R. Tymerski and V. Vorperian, "Generation and classification of PWM dc-to-dc converters," IEEE Trans. Aerosp. Electron. Syst., Vol. 24, No. 6, pp. 743-754, Nov. 1988.

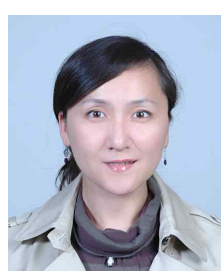

Yan Li was born in Heilongjiang Province, China, in 1977. She received her B.S. and M.S. degrees in Electrical Engineering from Yanshan University, Qinhuangdao, China, in 1999 and 2003, respectively, and her Ph.D. degree in Electrical Engineering from Nanjing University of Aeronautics and Astronautics, Nanjing, China, in 2009. From 1999 to 2009, she was at Yanshan University. Since 2009, she has been in the School of Electrical Engineering, Beijing Jiaotong University, Beijing, China. Her current research interests include multiple-input $\mathrm{dc} / \mathrm{dc}$ converters, renewable power systems, and PV grid-tied systems.



Trillion Q. Zheng (M'06-SM'07) was born in Jiangshan, Zhejiang Province, China, in 1964. He received his B.S. degree in Electrical Engineering from Southwest Jiaotong University, Sichuan, China, in 1986, and his M.S. and Ph.D. degrees in Electrical Engineering from Beijing Jiaotong University, Beijing, China, in 1992 and 2002, respectively. From 2003 to 2011, he served as the Dean of the School of Electrical Engineering at Beijing Jiaotong University. $\mathrm{He}$ is currently a University Distinguished Professor at Beijing Jiaotong University. He directs the Center for Electric Traction, founded by the Ministry of Education, China. His current research interests include power supplies and $\mathrm{AC}$ drives for railway traction systems, high performance and low loss power electronics systems, PV based converters and control, and active power filters and power quality correction. He holds 17 patents in China, and has published over 60 journal articles and more than 100 technical papers in conference proceedings. He is presently the Deputy Director for the council of the Beijing Society for Power Electronics and a Member of the council of China Electrotechnical Society. He received the Excellent Teacher Award from the Beijing Government (1997), and the Youth Award of Railway Science and Technology of Zhan Tianyou (2005). He was laureate of the Youth Elite of Science and Technology of the Railway Ministry of China (1998) and of the Zhongda Scholar for work in the areas of power electronics and motor drives, from the Delta Environmental and Educational Foundation (2007)

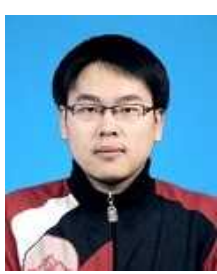

Qian Chen was born in Zhejiang Province, China, in 1987. He received his B.S. degree in Electronic Engineering from Beijing Jiaotong University, Beijing, China, in 2009. $\mathrm{He}$ is presently working toward his Ph.D. degree at Beijing Jiaotong University. His current research interests include power conversions and spacecraft power systems. 